\title{
Landscape Models for Simulating Water Quality at Point, Field, ANd Watershed Scales
}

\author{
P. Srivastava, K. W. Migliaccio, J. Šimůnek
}

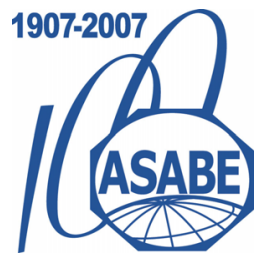

\begin{abstract}
In the last four decades, a plethora of models has been developed to simulate nonpoint-source (NPS) pollutant fate and transport at point, field, and watershed scales. Developed by experts in various disciplines, these models tend to reflect the needs of those disciplines. For example, the original intent of the solute transport models was to determine impact of water, nutrient, and salts on plant growth. Later, these models were extended to examine solute transport in the vadose zone to assess possible contamination of soil and groundwater. Similarly, a number of field-and watershed-scale models have been developed by linking together submodels of system components to quantify best management practice (BMP) effectiveness and watershed-level impact. New model users are often unaware of the suite of models available and are often uncertain about the appropriateness of models for their situation. The goals of this article are to discuss why NPS pollutant models were developed at various spatial scales (i.e., scale issues), briefly review commonly used models, and reflect on the future of landscape NPS models. Since the computational power of computers has significantly increased, automated data acquisition systems that can capture and transmit data at high resolution are being used, software that can handle large volumes of data has been developed, and improved chemical analysis capabilities are being developed, we conclude this article with the projection that development of a scale-independent model that can address complex issues of the next century by coupling state-of-the-art understanding of multiple hydrogeological, geochemical, and microbiological processes is possible. Future improvement in these models will result in a more scientific and robust approach for managing NPS pollutants.
\end{abstract}

Keywords. Field, Hydrology, Model, Runoff, Scaling, TMDL, Water quality, Watershed.

$\mathrm{M}$ odeling nonpoint-source (NPS) pollutant fate and transport processes across multiple scales is fundamental to addressing a number of environmental and natural resource issues, including degradation of soil and contamination of surface and ground waters. Landscape NPS models are currently used for a variety of purposes, including registration of pesticides and other agrochemicals, designing soil conservation practices, water table management, prevention of chemical pollution of surface water bodies and groundwater, protection of aquatic biota and development of Total Maximum Daily Loads (TMDLs). Virtually all federal agencies currently have their own models or support models developed elsewhere. According to Singh and Woolhiser (2002), "In the years ahead, the models will become even more common and will play an increasing role in our day-to-day lives."

Submitted for review in March 2007 as manuscript number SW 6915; approved for publication by the Soil \& Water Division of ASABE in June 2007 as a contribution to the ASABE 100th Anniversary Soil and Water Invited Review Series.

The authors are Puneet Srivastava, ASABE Member Engineer, Assistant Professor, Department of Biosystems Engineering, Auburn University, Auburn, Alabama; Kati W. Migliaccio, ASABE Member Engineer, Assistant Professor, Extension Specialist, Institute of Food and Agricultural Sciences, Department of Agricultural and Biologica Engineering, University of Florida, Homestead, Florida; and Jiri Šmůnek, Professor, Department of Environmental Sciences, University of California, Riverside, California. Corresponding author: Puneet Srivastava, Department of Biosystems Engineering, Auburn University, 200 Corley Bldg., Auburn, AL 36849; phone: 334-844-7426; fax: 334-844-3530; e-mail: srivapu@auburn.edu.
Since NPS pollutant transport is mainly driven by meteorological events, the early to mid-20th century saw the development of mathematical descriptions of individual hydrologic components (e.g., infiltration, runoff, evapotranspiration, and interception). The digital revolution of $1960 \mathrm{~s}$ witnessed the integration of individual hydrologic components (Singh and Woolhiser, 2002) into functional models that can be applied at various spatial and temporal scales. The development of NPS models in the U.S. began in response to the Clean Water Act (Arnold and Fohrer, 2005). Examples of these models include AGNPS (Young et al., 1987), AnnAGNPS (Bingner and Theurer, 2003), ANSWERS (Bouraoui and Dillaha, 1996, 2000), APEX (Williams and Izaurralde, 2005), CREAMS (Knisel 1980), DRAINMOD (Skaggs, 2007), EPIC (Williams et al., 1984), GLEAMS (Leonard et al., 1987; Knisel and Davis, 1999), GWLF (Haith and Shoemaker, 1987), HSPF (Bicknell et al., 2001), HYDRUS (Šimůnek et al., 2005, 2006), KINEROS (Woolhiser et al., 1990), LEACHM (Hutson and Wagenet, 1992), MACRO (Jarvis, 1994), NLEAP (Shaffer et al., 1991), RUSLE (Renard et al., 1991), RZWQM (Ahuja and Hebson, 1992), SWAT (Neitsch et al., 2002), and WEPP (Laflen et al., 1991). These models tend to be scale dependent and are usually suited for profile/horizon/pedon (point scale), field/farm (field scale), or watershed scale; however, there are a few exceptions.

The land phase of the hydrologic cycle is complicated and includes a great deal of uncertainty (Singh and Woolhiser, 2002) because of the spatial and temporal heterogeneity of soil properties, land use, precipitation, etc. Currently, a model that simultaneously operates at multiple spatial scales does not exist (the hierarchies of scales at which NPS models are 
often developed and applied are highlighted in gray in fig. 1). Because a scale-independent NPS model currently does not exist, two or more models are required for simultaneous simulations at different spatial scales. Use of a watershed-scale model for identifying hotspots of NPS pollution and a field-scale model for evaluating the specified fields (i.e., the hotspots) to optimize best management practice (BMP) efforts provides an example of multi-scale modeling. A watershed model alone cannot be used because either (1) the definition of fields does not exist or has been replaced by subwatersheds (or hydrologic response units (HRUs)) or regular-sized grids (or cells), or (2) many of the field-scale BMPs (e.g., riparian areas, grassed waterways) cannot be easily simulated. Current attempts to bring several models under the same framework are limited to sophisticated geographic information system (GIS) interfaces that preand post-process data for several models through the use of a single graphical user interface (GUI). Examples of such attempts are the U.S. Environmental Protection Agency's (USEPA) Better Assessment Science Integrating Point and Nonpoint Sources (BASINS) (USEPA, 2007) modeling system and the Watershed Modeling System (WMS) developed by Brigham Young University (EMSI, 2007).

The goals of this article are to discuss why NPS pollutant models were developed at various spatial scales (i.e., scale issues), briefly review commonly used models, and reflect on the future of landscape NPS models.

\section{SCALE ISSUES WITH LANDSCAPE NPS Pollutant Models}

Soil properties exhibit considerable spatial and temporal variability (Corwin and Wagenet, 1996; Corwin et al., 2006). Corwin et al. (1997) and Corwin et al. (2006) provide a number of useful references on this subject. Because of the variability of soil properties, "the movement of water and solute through the vadose zone is a complex, three-dimensional process" (Woods et al., 2006). At field and watershed scales, the transport of water and pollutants is affected by surface and subsurface boundary conditions (e.g., energy balance, precipitation, depth of water table, and depth of impermeable layer) and state variables (e.g., soil hydraulic and transport properties) that vary considerably in space and time (Woods et al., 2006).

Since model development at a particular scale requires observed data at that scale, a model developed at one scale is not always appropriate for application at a different scale (Corwin et al., 2006). Modeling NPS pollutant transport across multiple spatiotemporal scales can only be achieved by understanding the interrelationship between scale and spatial variability (Corwin et al., 2006). Issues of spatial and temporal variability and hence spatial and temporal scaling have received considerable attention since 1980s. Yet "scale and scaling continue to be significant issues" (Sivapalan et al., 2004). Both upscaling (transfer functions) and downscaling techniques are being explored. Upscaling refers to deriving effective parameters describing a system's behavior and average fluxes at a higher scale (e.g., at a field scale) (Vanderborght et al., 2006). Downscaling refers to constructing subscale heterogeneity from information obtained at a particular scale (Bierkens et al., 2000). There are a number of excellent discussions on scaling issues in hydrology and NPS pollutant transport (e.g., Corwin et al., 2006; Wagenet and Hutson, 1996; Singh and Woolhiser, 2002). Further, Corwin et al. (2006) provide a number of important references on this topic.

Regardless of the scale, a model must sufficiently account for the predominant processes at that scale. Further, the sampling and measurement approaches should be consistent with that scale (Wagenet and Hutson, 1996; Singh and Woolhiser, 2002; Corwin et al., 2006). Because complex local patterns of solute transport are attenuated and dominated by macroscale characteristics, mechanistic models are more common at the point scale, whereas functional and stochastic models are appropriate for field and watershed scales (Corwin et al. 2006).

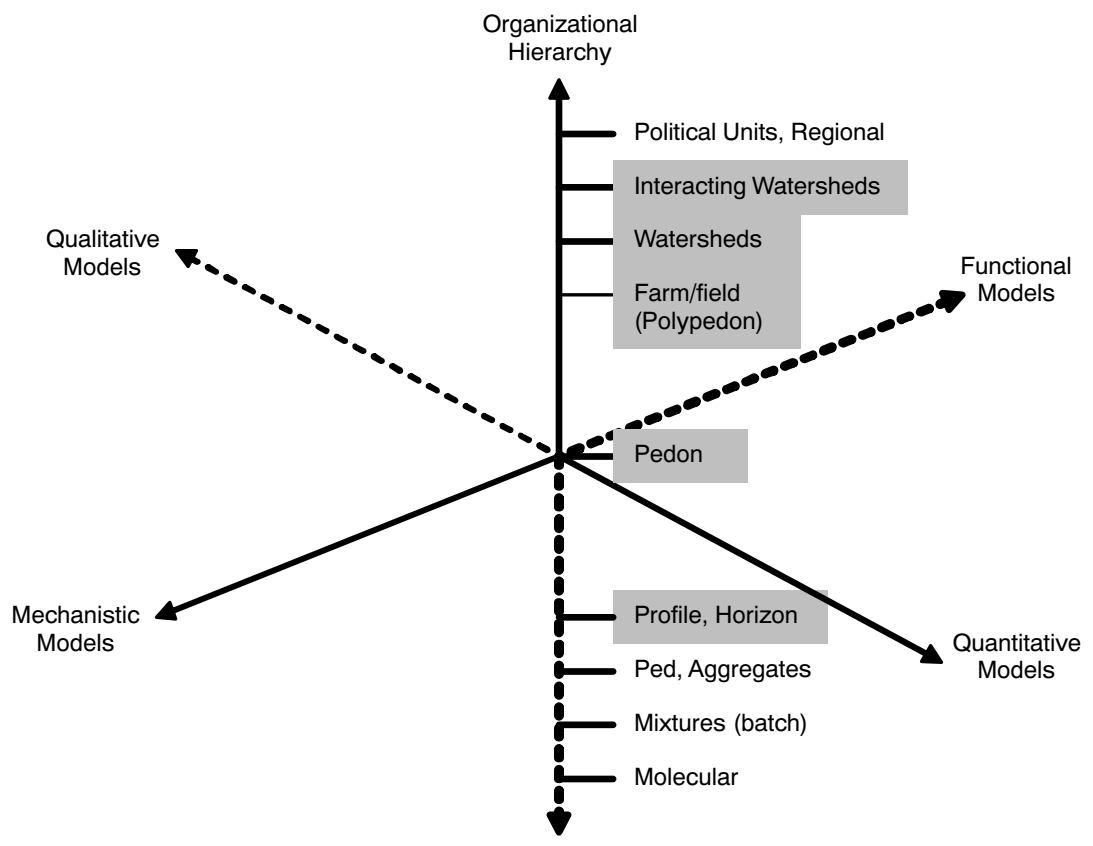

Figure 1. Organizational hierarchy of spatial scales at which NPS pollutant models can be developed and applied (redrawn after Hoosbeek and Bryant, 1992). The discussion in this article focuses on the scales (point, field, and watershed scales) highlighted in gray. 


\section{Models Applied at Various Scales}

Because of the variability of soil properties and meteorological events, scaling issues, and the need to address NPS pollution at several spatial and temporal scales, numerous point-, field-, and watershed-scale models have been developed. Further, because scaling issues have not been resolved, a variety of processes are being modeled at different scales.

\section{Point-Scale Models}

Many point-scale models have been developed to quantify the basic physical and chemical processes in the unsaturated zone. These models have a varying degree of complexity and dimensionality and are often focused on processes affecting water flow, heat transport, and movement of different nutrients, pollutants, and/or pathogens in the subsurface. While analytical and semi-analytical models (e.g., Šimůnek et al., 1999) of heat or solute transport can be applied under steadystate flow conditions, more complex numerical codes permit consideration of a large number of simultaneous nonlinear processes.

\section{Processes Simulated in Point-Scale Models}

Any quantitative analysis of the point-scale transport of energy, nutrients, pollutants, and/or pathogens must first evaluate water fluxes into and through the vadose zone. Water flow in variably saturated porous media is usually described using the Richards equation (Richards, 1931). Since the Richards equation is generally highly nonlinear, it usually requires a numerical solution. Solute transport and heat movement in the point-scale models are usually based on convection-dispersion (CDE) type governing equations. These equations can be extended to account for additional processes, such as volatilization and diffusion of contaminants in the gas phase, or storage and transfer of latent heat.

\section{Commonly Used Point-Scale Models}

Only relatively simplified system-independent boundary conditions were implemented in the earlier models (e.g., van Genuchten, 1987). Models developed recently can cope with much more complex system-dependent boundary conditions for which the actual boundary conditions depend on the status of the system and are calculated by the model itself. The boundary representing the soil-air interface is one example of a system-dependent boundary. Point-scale models have become increasingly sophisticated in terms of handling this upper boundary condition. They can commonly evaluate surface flow and energy balances and account for the simultaneous movement of water vapor and heat. Examples are DAISY, TOUGH2, SHAW, SWAP, HYDRUS-1D (Saito et al., 2006), UNSATH, and COUP (see table 1 for references).

Many environmental models, such as DAISY, LEACHM (Hutson and Wagenet, 1992), RZWQM, COUP, and HYDRUS (2D/3D), provide, as a standard feature, options to simulate carbon and nitrogen cycles. These models typically distribute organic matter, carbon, and organic and mineral nitrogen over multiple computational pools, while allowing organic matter to be decomposed by multiple microbial biomass populations.

The most dramatic improvements in the currently used models likely occurred in the type and complexity of solute transport processes that can be simulated. Current transport models can now consider a variety of nonlinear sorption and exchange processes, physical and chemical nonequilibrium transport, volatilization, gas diffusion, colloid attachment/ detachment, decay chain reactions, and many other processes. For example, the general formulation of the transport equations in the HYDRUS codes allows users to simulate a variety of contaminants, such as viruses (Schijven and Šimůnek, 2002), colloids (Bradford et al., 2002), trace elements (Seuntjens et al., 2001, Carrillo-González et al., 2006), hormones (Casey et al., 2003), explosives (Dontsova et al., 2006), or chemicals involved in the sequential biodegradation (Schaerlaekens et al., 1999; Casey and Šimůnek, 2002).

The transport of reactive contaminants in the subsurface is generally affected by a large number of nonlinear and often interactive physical, chemical, and biological processes. Simulating these processes requires comprehensive reactive transport codes that couple the physical processes of water flow and advective-dispersive transport with a range of biogeochemical processes, such as surface complexation, precipitation/dissolution, cation exchange, and/or biological reactions (Šimůnek and Valocchi, 2002). Models that simulate the transport of major ions, such as RZWQM, LEACHM, and HYDRUS-1D, and various reclamation models (Šimůnek and Valocchi, 2002) are typical examples of such coupled models. Models with more general chemistry were recently reviewed by Šimůnek and Valocchi (2002) and Jacques et al. (2006). Users of these models can select species and reactions from large geochemical databases. Examples of codes with general geochemistry are, for example, PHREEQC (Parkhurst and Appelo, 1999), CRUNCH (Steefel, 2000), PHAST (Parkhurst et al., 2004), 3DHYDROGEOCHEM (Yeh and Cheng, 1999), and HP1 (Jacques and Šimůnek, 2005).

Existing models are often extended so that they can be applied to situations where preferential flow occurs. MACRO and HYDRUS-1D are example of such models. Possible approaches for simulating preferential flow range from relatively simple, physically based, dual-porosity models to more complex dual-permeability and multi-region models. Dual-porosity, mobile-immobile water flow models consider that flow occurs in preferential flow paths, while immobile water is assumed to exist in the matrix or soil aggregates. On the other hand, dual-permeability models assume that water is mobile in both the matrix and fracture domains.

Existing models vary widely in terms of their complexity, sophistication, and ease of use. Table 1 summarizes the more widely used numerical models for simulating variably saturated water flow and solute transport in soils.

\section{Field-SCAle Models}

Numerous field-scales models have been developed to determine the effectiveness of BMPs on transport of sediment, nutrients (nitrogen and phosphorus), and pesticides from agricultural management systems. These models simulate water quality constituents leaving the edge of the field through surface runoff and leaving the vadose zone through leaching, transport of dissolved constituents in tile drains, and transport of dissolved constituents leaving the edge of the field through lateral flow.

\section{Processes Simulated in Field-Scale Models}

Contrary to point-scale models that describe water flow using the Richards equation and solute transport using CDE, process-based field-scale models often link together a number of empirically derived submodels to simulate: (1) various 
Table 1. Some of the widely used numerical models for simulating variably saturated water flow and solute transport in soils at the point scale (adapted from Šimůnek, 2005).

\begin{tabular}{|c|c|c|}
\hline Model (Reference) & Features & Internet Address \\
\hline $\begin{array}{l}\text { COUP } \\
\text { (Jansson and } \\
\text { Karlberg, 2001) }\end{array}$ & $\begin{array}{l}\text { Carbon/nitrogen cycle, thawing/freezing cycle, coupled water, vapor, and } \\
\text { heat transport, meteorological input, crop growth. }\end{array}$ & $\begin{array}{l}\text { www.lwr.kth.se/Vara\%20Datorprogram/ } \\
\text { CoupModel/ }\end{array}$ \\
\hline $\begin{array}{l}\text { DAISY } \\
\text { (Hansen et al., 1990) }\end{array}$ & $\begin{array}{l}\text { Carbon/nitrogen cycle, multi-year crop growth cycles, management practices, } \\
\text { pesticide processes. }\end{array}$ & www.dina.dk/ daisy/ \\
\hline $\begin{array}{l}\text { HP1 } \\
\text { (Jacques and } \\
\text { ¿imének, 2005) }\end{array}$ & $\begin{array}{l}\text { Coupled HYDRUS-1D with the PHREEQC geochemical code (Parkhurst and } \\
\text { Appelo, 1999), transient water flow, transport of multiple components, mixed } \\
\text { equilibrium/kinetic biogeochemical reactions, and heat transport. }\end{array}$ & www.sckcen.be/hp1 \\
\hline $\begin{array}{l}\text { HYDRUS-1D } \\
\text { (改它nek et al., 2005) }\end{array}$ & $\begin{array}{l}\text { Multiple soil hydraulic functions, neural network based pedotransfer } \\
\text { functions, nonlinear nonequilibrium solute transport, mobile-immobile and } \\
\text { two-site sorption concepts, chain reactions, volatilization, major ion } \\
\text { chemistry, transport of colloids and bacteria, inverse option, intuitive } \\
\text { sophisticated graphical user interface. }\end{array}$ & www.hydrus 2 d.com \\
\hline 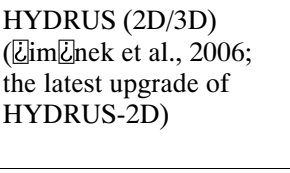 & $\begin{array}{l}\text { Two- and three-dimensional, multiple soil hydraulic functions, neural } \\
\text { network based pedotransfer functions, nonlinear nonequilibrium solute } \\
\text { transport, mobile-immobile and two-site sorption concepts, chain reactions, } \\
\text { transport of colloids and bacteria, inverse option, unstructured triangular } \\
\text { finite element meshes, intuitive sophisticated graphical user interface (GUI). }\end{array}$ & www.hydrus2d.com \\
\hline $\begin{array}{l}\text { MACRO } \\
\text { (Jarvis, 1994) }\end{array}$ & $\begin{array}{l}\text { Preferential flow using kinematic wave equation, snow accumulation, } \\
\text { pesticide transport, compensated root water uptake. }\end{array}$ & www.mv.slu.se/BGF/Macrohtm/macro.htm \\
\hline $\begin{array}{l}\text { RZWQM } \\
\text { (Ahuja and Hebson, } \\
\text { 1992) }\end{array}$ & $\begin{array}{l}\text { Complex modular program, crop growth, chemical equilibrium module, } \\
\text { management practices, transport of nutrients, pesticide processes, input of } \\
\text { meteorological variables. }\end{array}$ & http://gpsr.ars.usda.gov/products/rzwqm.htm \\
\hline $\begin{array}{l}\text { SHAW } \\
\text { (Flerchinger et al., 1996) }\end{array}$ & $\begin{array}{l}\text { Thawing/freezing cycle, coupled water, vapor, and heat transport, } \\
\text { multi-species plant canopy, input of meteorological variables. }\end{array}$ & www.nwrc.ars.usda.gov/models/shaw \\
\hline $\begin{array}{l}\text { SWAP } \\
\text { (van Dam et al., 1997) }\end{array}$ & $\begin{array}{l}\text { Three-level drainage system at regional scale, crop growth, swelling soils, } \\
\text { input of meteorological variables. }\end{array}$ & www.swap.alterra.nl/ \\
\hline $\begin{array}{l}\text { SWIM } \\
\text { (Verburg et al., 1996) }\end{array}$ & $\begin{array}{l}\text { Bypass flow, flexible description of hydraulic properties, hyperbolic sine } \\
\text { transformation of the pressure head. }\end{array}$ & www.clw.csiro.au/products/swim \\
\hline $\begin{array}{l}\text { TOUGH } 2 \\
\text { (Pruess, 1991) }\end{array}$ & $\begin{array}{l}\text { Multidimensional multiphase fluid and heat flow, multicomponent transport, } \\
\text { dual permeability flow and transport, very hard to use. }\end{array}$ & www-esd.lbl.gov/TOUGH2/ \\
\hline $\begin{array}{l}\text { UNSATH } \\
\text { (Fayer, 2000) }\end{array}$ & $\begin{array}{l}\text { Coupled water, vapor, and heat transport, no solute transport, input of } \\
\text { meteorological variables. }\end{array}$ & $\begin{array}{l}\text { http://hydrology.pnl.gov/resources/ } \\
\text { unsath/unsath_download.asp }\end{array}$ \\
\hline $\begin{array}{l}\text { VS2DT } \\
\text { (Healy, 1990) }\end{array}$ & Two-dimensional water flow and solute transport, finite differences. & http://water.usgs.gov/software/vs2di.html \\
\hline
\end{tabular}

components of the land phase of the hydrologic cycle, and (2) the fate and transport of sediment, nutrients, and pesticides. Currently, these models are not designed to simulate pathogen transport (table 2). Many of the currently used field-scales models have their roots in CREAMS, GLEAMS, and DRAINMOD.

CREAMS estimates surface runoff, percolation, soil erosion and sediment yield, dissolved and sediment-bound nutrients, plant uptake of nutrients, and transport and transformation of pesticides (Knisel, 1980). Hydrologic response simulation includes models for infiltration, soil water movement, and evapotranspiration between storms. Surface runoff and infiltration are simulated using the SCS curve number $(\mathrm{CN})$ method or the Green-Ampt equation. Water movement through the soil profile is modeled using a simple capacity approach, with flow occurring when a layer exceeds field capacity. The evapotranspiration model is taken from Ritchie (1972). Erosion is simulated using the USLE approach, while sediment transport is modeled based on transport capacity of overland flow using Yalin's sediment transport equation (Foster and Meyer, 1972). The erosion/deposition feature simulates concentrated flow within the field (e.g., terrace channels, diversions, major flow concentrations where topography causes overland flow conversion, and grassed waterways). The channel element does not describe gully or stream channel erosion. The plant nutrient submodel contains a nitrogen component that considers mineralization, nitrification, and denitrification processes; a plant uptake component; and a nitrate leaching component. The pesticide component considers foliar interception, degradation, and wash-off, as well as adsorption, desorption, and degradation in the soil. The nitrogen, phosphorus, and pesticide components use enrichment ratios to estimate the portions of these constituents transported with sediment (Knisel, 1980).

GLEAMS was developed to remove weaknesses of CREAMS (Knisel, 1993). GLEAMS provides a more detailed simulation of water, sediment, nutrient, and pesticide movement in surface runoff and subsurface flows. PriestlyTaylor and Penman-Monteith methods are used for potential evapotranspiration, while actual soil evaporation and plant transpiration are simulated after Ritchie (1972). The plant nutrient component includes ammonification, nitrification, denitrification, uptake, fixation, leaching, and runoff of nitrogen, and mineralization, uptake, leaching, and runoff of phosphorus. GLEAMS represents nitrogen fixation more adequately than CREAMS. The GLEAMS model represents nitrogen fixation by legume; fertigation; application of animal waste as solid, slurry, or liquid through irrigation systems; and tillage. In addition, GLEAMS considers movement of phosphorus in subsurface flows and vertical flux of pesticides into, within, and through the root zone (table 2). The major limitation of both CREAMS and GLEAMS is that they can- 
not be applied in areas influenced by urbanization and in landscapes with substantially altered hydrology due to artificial drainage.

DRAINMOD combines the original DRAINMOD hydrology with DRAINMOD-N (Brevé et al., 1997) and DRAINMOD-S (Kandil et al., 1995). The combined model simulates the hydrology of poorly drained, high water table soils; predicts the effects of drainage (open ditches and subsurface tiles) and associated water management practices on water table depths, soil water regime, crop yields (Skaggs, 2007); and models one-dimensional transport of nitrogen using an advective-dispersive-reactive equation (DRAINMOD-N). DRAINMOD-S predicts salinity in semiarid and arid lands. The model can evaluate long-term performance of drainage systems (using the Houghoudt and Kirkham equations), subirrigation, controlled drainage, and wastewater application to artificially drained soils. Infiltration (Green-Ampt equation), potential evapotranspiration (Thornthwaite method), and actual evapotranspiration are also simulated. DRAINMOD is not generally applicable for areas that do not experience high water tables.

\section{Other Commonly Used Field-Scale Models}

Other common field-scale models include ADAPT, APEX, EPIC, and FHANTM. ADAPT, a water table management model, is an extension of DRAINMOD and GLEAMS for pesticide transport in agricultural environments. APEX, an extension of EPIC for whole farm and small watersheds, evaluates land management strategies considering sustainability, erosion (wind, sheet, and channel), economics, water supply and quality, soil quality, plant competition, weather, and pests. Management capabilities include irrigation, drainage, furrow diking, buffer strips, terraces, waterways, fertilization, manure management, lagoons, reservoirs, crop rotation and selection, pesticide application, grazing, and tillage. APEX can be used for evaluating the effects of global climate $/ \mathrm{CO}_{2}$ changes, designing environmentally safe and economic landfill sites, designing biomass production systems for energy, and other spin-off applications (Williams and Izaurralde, 2005). APEX is one of the few models that routes water, sediment, nutrients, and pesticides across complex landscapes and channel systems to the outlet of small watersheds. It has been applied to watersheds as large as $1000 \mathrm{~km}^{2}$. The model contains groundwater and reservoir components that are usually missing from other field-scale models. The submodels in APEX are based on EPIC, CREAMS, and GLEAMS.

EPIC, which was originally developed to assess the effect of soil erosion on soil productivity, has been expanded to allow simulation of hydrology, erosion-sedimentation, nutrient cycling, pesticide fate, plant growth, soil temperature, tillage, economics, and plant environment control. The economic component of EPIC estimates the cost of producing and marketing crops. FHANTM is mainly designed for flat fields with the high water table environment of Florida; the hydrology is based on DRAINMOD, and the nutrient transport is based on GLEAMS.

\section{Watershed-Scale Models}

Watershed-scale models are a result of the combination of two modeling concepts: landscape modeling and lotic/lentic modeling. The coalescence of landscape and water-routing models has been timely due to the interest in addressing water pollutant concerns that are characterized as having diverse and diffuse potential sources, namely NPS pollution. Thus, watershed-scale models are generally applied to understand or quantify a relationship between landscape activities and downstream water quality or quantity. Watershed-scale models vary in the processes they simulate (table 3 ).

Table 2. Some of the widely used field-scale models for simulating runoff, sediment, nutrients, and pesticides leaving the edge-of-the-field and leaching through the root zone.

\begin{tabular}{|c|c|c|c|c|c|c|c|c|c|c|c|c|c|c|c|c|c|c|c|}
\hline \multirow[b]{4}{*}{ Model } & \multirow{4}{*}{$\begin{array}{c}\text { Time } \\
\text { Scale }^{[\mathrm{a}]}\end{array}$} & \multirow{4}{*}{$\begin{array}{c}\text { Time } \\
\text { Ste }^{[\mathrm{b}]}\end{array}$} & \multicolumn{17}{|c|}{ Processes Simulated } \\
\hline & & & & & & & & & Nutr & ients [ & & & & & & & & & \\
\hline & & & \multicolumn{2}{|c|}{$\underline{\text { Hydrology }[\mathrm{c}]}$} & \multicolumn{3}{|c|}{$\underline{\text { Sediment }} t^{[\mathrm{f}]}$} & \multicolumn{2}{|c|}{ Nitrogen } & \multicolumn{2}{|c|}{ Phosphorus } & \multicolumn{2}{|c|}{ Pesticides $[\mathrm{c}]$} & \multicolumn{2}{|c|}{$\underline{\text { Pathogens }[\mathrm{c}]}$} & \multicolumn{4}{|c|}{ Mass Balance[g] } \\
\hline & & & $\mathrm{S}^{[\mathrm{d}]}$ & $\mathrm{SS}[\mathrm{e}]$ & $\mathrm{E}$ & $\mathrm{T}$ & $\mathrm{Y}$ & $\mathrm{S}$ & SS & $\mathrm{S}$ & SS & $\mathrm{S}$ & SS & $\mathrm{S}$ & SS & W & $\mathrm{N}$ & $\mathrm{P}$ & Pest. \\
\hline \multicolumn{20}{|c|}{ ADAPT (Chung et al., 1992) } \\
\hline & $\mathrm{C}$ & $\mathrm{D}$ & OF,CFF & $\mathrm{SM}, \mathrm{AD}, \mathrm{LF}$ & $\mathrm{Y}$ & $\mathrm{Y}$ & $\mathrm{Y}$ & $\mathrm{Y}$ & $\mathrm{Y}$ & $\mathrm{Y}$ & $\mathrm{Y}$ & $\mathrm{Y}$ & $\mathrm{Y}$ & -- & -- & $\mathrm{Y}$ & $\mathrm{Y}$ & $\mathrm{Y}$ & $\mathrm{Y}$ \\
\hline \multicolumn{20}{|c|}{ APEX (Williams and Izaurralde, 2005) } \\
\hline & $\mathrm{C}$ & H,D & $\mathrm{OF}, \mathrm{CF}$ & SM,AD,LF & $\mathrm{Y}$ & $\mathrm{Y}$ & $\mathrm{Y}$ & $\mathrm{Y}$ & $\mathrm{Y}$ & $\mathrm{Y}$ & $\mathrm{Y}$ & $\mathrm{Y}$ & $\mathrm{Y}$ & -- & -- & $\mathrm{Y}$ & $\mathrm{Y}$ & $\mathrm{Y}$ & $\mathrm{Y}$ \\
\hline \multicolumn{20}{|c|}{ CREAMS (Knisel 1980) } \\
\hline & E,C & H,D & OF,CFF & SM,LF & $\mathrm{Y}$ & $\mathrm{Y}$ & $\mathrm{Y}$ & $\mathrm{Y}$ & $\mathrm{Y}$ & $\mathrm{Y}$ & -- & $\mathrm{Y}$ & -- & -- & -- & $\mathrm{Y}$ & Y & $\mathrm{Y}$ & $\mathrm{Y}$ \\
\hline \multicolumn{20}{|c|}{ DRAINMOD (Skaggs, 2007) } \\
\hline & $\mathrm{C}$ & H,D & $\mathrm{OF}, \mathrm{CFF}$ & $\mathrm{SM}, \mathrm{AD}$ & -- & -- & -- & $\mathrm{Y}$ & $\mathrm{Y}$ & -- & -- & -- & -- & -- & -- & $\mathrm{Y}$ & $\mathrm{Y}$ & -- & -- \\
\hline \multicolumn{20}{|c|}{ EPIC (Williams et al., 1984) } \\
\hline & $\mathrm{C}$ & $\mathrm{D}$ & $\mathrm{OF}, \mathrm{CF}$ & $\mathrm{SM}, \mathrm{AD}, \mathrm{LF}$ & $\mathrm{Y}$ & -- & $\mathrm{Y}$ & $\mathrm{Y}$ & $\mathrm{Y}$ & $\mathrm{Y}$ & $\mathrm{Y}$ & $\mathrm{Y}$ & $\mathrm{Y}$ & -- & -- & $\mathrm{Y}$ & $\mathrm{Y}$ & $\mathrm{Y}$ & $\mathrm{Y}$ \\
\hline \multicolumn{20}{|c|}{ FHANTM (Tremwel, 1992) } \\
\hline & $\mathrm{C}$ & H,D & $\mathrm{OF}, \mathrm{CFF}$ & $\mathrm{SM}, \mathrm{AD}, \mathrm{LF}$ & -- & -- & -- & $\mathrm{Y}$ & $\mathrm{Y}$ & $\mathrm{Y}$ & $\mathrm{Y}$ & -- & -- & -- & -- & $\mathrm{Y}$ & $\mathrm{Y}$ & $\mathrm{Y}$ & -- \\
\hline \multicolumn{20}{|c|}{$\begin{array}{l}\text { GLEAMS (Leonard et al., 1987; Knisel and Davis, 1999) } \\
\end{array}$} \\
\hline & $\mathrm{C}$ & $\mathrm{D}$ & $\mathrm{OF}, \mathrm{CFF}$ & SM,LF & $\mathrm{Y}$ & $\mathrm{Y}$ & $\mathrm{Y}$ & $\mathrm{Y}$ & $\mathrm{Y}$ & $\mathrm{Y}$ & $\mathrm{Y}$ & $\mathrm{Y}$ & $\mathrm{Y}$ & -- & -- & $\mathrm{Y}$ & $\mathrm{Y}$ & $\mathrm{Y}$ & $\mathrm{Y}$ \\
\hline
\end{tabular}

[a] $\mathrm{C}=$ continuous; $\mathrm{E}=$ event.

[b] $\mathrm{H}=$ hourly; $\mathrm{D}=$ daily. This is the computational and/or output time step at which the model operates. This does not mean that the outputs generated are good for that time step. Quite often, model outputs are good for a time step that is larger than the computational time step. For example, if the computational time step is daily, then monthly predictions are more appropriate for analysis.

[c] $\mathrm{S}=$ surface; $\mathrm{SS}=$ subsurface.

[d] $\mathrm{OF}=$ overland flow; $\mathrm{CF}=$ channel flow; $\mathrm{CFF}=$ channel flow in field only.

[e] $\mathrm{SM}=$ soil moisture; $\mathrm{AD}=$ artificial drainage (e.g., subsurface tiles); $\mathrm{LF}=$ lateral flow.

[f] $\mathrm{E}=$ erosion; $\mathrm{T}=$ transport; $\mathrm{Y}=$ yield

[g] $\mathrm{W}=$ water, $\mathrm{N}=$ nitrogen; $\mathrm{P}=$ phosphorus; Pest. $=$ pesticide. 


\section{Processes Simulated in Watershed-Scale Models}

Watershed-scale models include hydrologic processes, such as precipitation, infiltration, surface runoff, evapotranspiration, subsurface (groundwater) flows, and stream flow. The landscape portions of the hydrologic cycle are commonly represented in a watershed-scale model using a water balance equation. Watershed-scale models differ in how each of the terms in the water balance equation is derived. For example, potential evapotranspiration (PET) may be estimated using Penman, Penman-Monteith, or some other algorithm. As with landscape processes, in-stream or reach water dynamics often use another common relationship, the continuity equation. The terms in the continuity equation are solved using numerical techniques that often include some form of the Manning equation (Bicknell et al., 2001; Neitsch et al., 2002). These hydrologic processes are discussed in greater detail by Migliaccio and Srivastava (2007).

In addition to hydrology, erosion and sediment transport are simulated in watershed-scale models. The predominant method used to estimate erosion is some form of the USLE equation, such as the MUSLE (Neitsch et al., 2002) or the RUSLE and HUSLE (Theurer and Clarke, 1991). Nitrogen and phosphorus cycles are also included in most watershedscale models, including landscape and in-stream processes. Other constituents, such as pesticides, bacteria, and conservatives (or tracers) are likewise simulated in some watershed-scale models.

Simulation of agricultural crops and their subsequent yield is less common in currently available watershed-scale models, one exception to this is SWAT. However, there is growing interest in using watershed-scale models to not only evaluate water quality concerns but also simulate the coupled response of crop yield and water quality. As the TMDL process continues to evolve, the ability to predict both reach water quality and crop yields will be crucial for selecting reasonable BMPs. A recent ASABE effort described by Muñoz-Carpena et al. (2006) resulted in a series of publications addressing TMDLs. TMDLs often require watershedlevel modeling; hence, several TMDL-related publications include relevant watershed modeling discussions (e.g., Benham et al., 2006; Borah et al., 2006; Vellidis et al., 2006; Yagow et al., 2006).

Simulation of NPS pollution at the watershed scale often requires inclusion of water bodies, such as reservoirs. Although watershed-scale models provide some representation of these systems, they do not provide the same simulation abilities as stand-alone reservoir models. If reservoir systems are fairly complex and influential on downstream water flows, it may be prudent to link a watershed-scale model to a more complex reservoir model (White et al., 2004; Debele et al., 2006).

\section{Commonly Used Watershed-Scale Models}

Watershed-scale models are relatively young compared to point-scale and field-scale models and are still evolving. However, several watershed-scale models have become more common in their application and appearance in published literature. These include AnnAGNPS (Yuan et al., 2001; Suttles et al., 2003), ANSWERS-2000 (Bouraoui and Dillaha, 2000; Niu et al., 2001), HSPF (Paul et al., 2004; Saleh and Du, 2004), SWAT (Saleh et al., 2000; White and Chaubey, 2005), and WAM (Ouyang, 2003; Bottcher et al., 2005). Additional information on these and other watershed- scale models may also be found in Bora and Bera (2003, 2004).

Four of the selected models were specifically designed to evaluate NPS pollutants from agricultural land uses: AnnAGNPS, ANSWERS-2000, SWAT, and WAM. Each model has unique features that should be considered in selection of a watershed-scale model for implementation. One difference among the four models is groundwater simulation. SWAT or WAM may be a preferred choice if stream hydrology is dominated by groundwater. The groundwater algorithms in ANSWERS-2000 currently simulate simplistic groundwater storage such that groundwater is evenly released into streams at a rate proportional to the volume of accumulated storage. AnnAGNPS is also limited in representing groundwater, as the model includes only interflow and subsurface/tile drainage.

Another watershed-scale model is HSPF, which is a hydrologic and water quality model often used to simulate stream bacteria (Paul et al., 2004; Benham et al., 2005). Although HSPF is one of the most comprehensive watershedscale models, its application may be more difficult for the user than that of other watershed-scale models. A comparison of SWAT and HSPF by Van Liew et al. (2003) indicated that the HSPF manual was less intuitive, input data preparation was cumbersome, and more parameters were required for calibrating hydrologic response in HSPF.

Unique to the set of models selected for our article is WAM. WAM consists of a collection of models that are applied at the cell level and managed by the BUCSHELL subprogram. The collection of land cell source models includes: GLEAMS, the Everglades Agricultural Area Model (EAAMOD), a wetland model, and an urban model. In other words, WAM uses field-scale models to simulate cell processes, which are then linked using BLASRoute, which routes waters and constituents through the watershed system.

\section{Future of LANDSCAPE NPS Models}

In past few decades, much of the research and model development effort has focused on surface water flow, variably saturated water flow in the vadose zone, and fate and transport processes of a few key pollutants (e.g., sediment, nitrogen, phosphorus, and pesticides). With the rapid technological development of society, the need to understand how manipulation of one component affects other parts of the system will continue to increase at a fast rate. The impact of producing bioenergy from crops, understanding the effect of climate variability and climate change, and the impact of emerging contaminants (e.g., nanoparticles, antimicrobials, hormones, pathogens, and other pharmaceuticals) provide just a few examples. Addressing the complex issues of the next century will require a systems approach that is based on a thorough understanding and coupling of multiple hydrogeological, geochemical, and microbiological processes.

Since the mid-1990s, a number of sophisticated GISbased GUIs have been developed that have substantially increased the use of NPS pollutant models. Currently available GIS-based modeling systems (e.g., BASINS and WMS) provide a common GUI for various models. However, moving from one spatial scale to another is still cumbersome, if not impossible. Further, the outputs provided by models applied at different spatial scales might not be compatible because of 
Table 3. Some of the widely used watershed-scale models for simulating hydrologic processes, nitrogen and phosphorus cycles, erosion, and pesticide transport from landscape environments into stream reaches.

\begin{tabular}{|c|c|c|c|c|c|}
\hline Process Simulated & $\begin{array}{l}\text { AnnAGNPS } \\
\text { (Bingner and } \\
\text { Theurer, 2003) }\end{array}$ & $\begin{array}{c}\text { ANSWERS-2000 } \\
\text { (Bouraoui and Dillaha, } \\
\text { 1996; Bouraoui and } \\
\text { Dillaha, 2000) }\end{array}$ & $\begin{array}{c}\text { HSPF } \\
\text { (Bicknell et al., 2001) }\end{array}$ & $\begin{array}{c}\text { SWAT } \\
\text { (Neitsch et al., 2002) }\end{array}$ & $\begin{array}{c}\text { WAM } \\
(\text { SWET, 2006) }\end{array}$ \\
\hline Surface hydrology & Modified SCS CN2 & Green-Ampt & Philip's equation & $\begin{array}{l}\text { Modified SCS CN2 } \\
\text { and Green Ampt }\end{array}$ & Modified SCS CN2 \\
\hline Groundwater hydrology & $\begin{array}{l}\text { Interflow and } \\
\text { subsurface/tile } \\
\text { drainage }\end{array}$ & $\begin{array}{c}\text { Subsurface/tile } \\
\text { drainage, shallow } \\
\text { aquifer }\end{array}$ & $\begin{array}{l}\text { Interflow, shallow } \\
\text { aquifer, deep aquifer }\end{array}$ & $\begin{array}{l}\text { Interflow, subsurface/ } \\
\text { tile drainage, shallow } \\
\text { aquifer, deep aquifer }\end{array}$ & $\begin{array}{l}\text { Interflow, shallow } \\
\text { aquifer, deep } \\
\text { aquifer }\end{array}$ \\
\hline $\begin{array}{l}\text { Potential } \\
\text { evapotranspiration }\end{array}$ & Penman & $\begin{array}{l}\text { Solar radiation, } \\
\text { temperature, and } \\
\text { albedo equation }\end{array}$ & $\begin{array}{l}\text { Input time series (not } \\
\text { estimated by the model) }\end{array}$ & $\begin{array}{l}\text { Penman-Monteith, } \\
\text { Priestly-Taylor, } \\
\text { Hargreaves }\end{array}$ & $\begin{array}{l}\text { Priestly-Taylor, } \\
\text { Penman-Monteith }\end{array}$ \\
\hline Erosion & RUSLE and HUSLE & $\begin{array}{c}\text { Relationships developed } \\
\text { by Meyer and } \\
\text { Wischmeier (1969) } \\
\text { and Yalin's modified } \\
\text { equation (Foster and } \\
\text { Meyer, 1972) }\end{array}$ & $\begin{array}{c}\text { Based on the ARM } \\
\text { and NPS models } \\
\text { (Donigian and Crawford, } \\
\text { 1976a, 1976b) }\end{array}$ & MUSLE & $\begin{array}{l}\text { Varies depending } \\
\text { on the land cell } \\
\text { source model } \\
\text { selected }\end{array}$ \\
\hline $\mathrm{P}$ and $\mathrm{N}$ fertilization & $\mathrm{Y}$ & $\mathrm{Y}$ & $\mathrm{Y}$ & $\mathrm{Y}$ & $\mathrm{Y}$ \\
\hline $\mathrm{P}$ and $\mathrm{N}$ transport & $\mathrm{Y}$ & $\mathrm{Y}$ & $\mathrm{Y}$ & $\mathrm{Y}$ & $\mathrm{Y}$ \\
\hline Pesticide application & $\mathrm{Y}$ & -- & $\mathrm{Y}$ & $\mathrm{Y}$ & -- \\
\hline Pesticide transport & $\mathrm{Y}$ & -- & $\mathrm{Y}$ & $\mathrm{Y}$ & -- \\
\hline Crop land management & $\mathrm{Y}$ & $\mathrm{Y}$ & -- & $\mathrm{Y}$ & $\mathrm{Y}$ \\
\hline Crop yield & -- & -- & -- & $\mathrm{Y}$ & $--[a]$ \\
\hline Output time step & Daily or subdaily & $\begin{array}{l}\text { Daily for dry days, } 30 \mathrm{~s} \\
\text { for precipitation days }\end{array}$ & $\begin{array}{l}\text { Hourly (user may select } \\
\text { number of hours) }\end{array}$ & Daily or subdaily & Daily \\
\hline Water bodies & $\begin{array}{l}\text { Stream reach } \\
\text { and reservoir }\end{array}$ & Stream reach & $\begin{array}{l}\text { Stream reach } \\
\text { and reservoir }\end{array}$ & $\begin{array}{l}\text { Stream reach } \\
\text { and reservoir }\end{array}$ & Stream reach \\
\hline Bacteria & -- & -- & $\mathrm{Y}$ & $\mathrm{Y}$ & -- \\
\hline Plankton and algae & -- & -- & $\mathrm{Y}$ & $\mathrm{Y}$ & -- \\
\hline Spatial representation & $\begin{array}{l}\text { Cells or hydrologic } \\
\text { response units }\end{array}$ & Cells & $\begin{array}{l}\text { Hydrologic } \\
\text { response units }\end{array}$ & $\begin{array}{l}\text { Hydrologic } \\
\text { response units }\end{array}$ & Cells \\
\hline Developer & $\begin{array}{l}\text { USDA-ARS, } \\
\text { USDA-NRCS }\end{array}$ & $\begin{array}{l}\text { Purdue University } \\
\text { and Virginia Tech }\end{array}$ & USEPA, USGS & USDA-ARS & $\begin{array}{l}\text { Soil and Water } \\
\text { Engineering } \\
\text { Technology, Inc. }\end{array}$ \\
\hline Web site & $\begin{array}{c}\text { www.ars.usda.gov/ } \\
\text { Research/ } \\
\text { docs.htm?docid=5199 }\end{array}$ & -- & $\begin{array}{c}\text { water.usgs.gov/ } \\
\text { software/hspf.html; } \\
\text { www.epa.gov/ } \\
\text { ceampubl/swater/hspf/ }\end{array}$ & $\begin{array}{l}\text { www.brc.tamus. } \\
\text { edu/swat/ }\end{array}$ & $\begin{array}{c}\text { www.swet.com/ } \\
\text { SoftwareWAM.html }\end{array}$ \\
\hline
\end{tabular}

the incompatibility of the physical basis of these models. Many NPS models (especially those that operate at field and watershed scales) also provide outputs at low temporal resolution (days, months, and years). For many toxic chemicals, a high enough concentration for a short period of time can significantly impact a surface water body. In addition to spatial and temporal scaling issues, currently available models are still relatively specialized, and a single model that can describe the multiple problems and chemicals mentioned above is presently unavailable.

In the last decade or so, significant effort has been directed towards developing technologies to capture data at high spatial and temporal resolutions. However, relatively little effort has been directed towards developing better understanding of scaling issues and the fundamental fate and transport processes at different scales. In next few decades, there will be a greater need to develop affordable sensors that can capture data on surface and subsurface boundary conditions and state variables at high spatial and temporal resolutions. The technologies that can help develop such sensors (e.g., nano- technology) and that can capture and transmit data (wireless engineering, database management systems, and GIS) are currently underway. These technologies will help develop better understanding of underlying fundamental processes and scaling issues.

In the next few decades, we will likely see improved input data resolution leading to better understanding of fundamental processes, resolution of spatial and temporal scaling issues, inclusion of state-of-the-art process-based understanding in models, and models that have high predictive capability and that can be applied at several spatial and temporal scales simultaneously. We will also see great improvements in GUIs, which will allow increased utilization of models for addressing a number of complex environmental issues. Improvement in data resolution will also help reduce input data uncertainty and develop true frequency distributions of various input parameters, which will lead to reduced output data uncertainty and increased utilization of uncertainty analysis. It is not unrealistic to envision a scaleindependent modeling system in the future that operates in 
real-time and provides signals to water managers regarding specific NPS pollution concerns, particularly those related to public health (e.g., drinking water, swimability, and fishability).

\section{SUMMARY}

The number of models developed at various spatial scales has exploded. Point-scale models are based on the mechanistic understanding developed at the point scale. However, upscaling to field and watershed scales is not currently possible because of the vast spatial and temporal variability of surface and subsurface boundary conditions and state variables. Hence, field- and watershed-scale models link together empirical submodels of system components. Further, these models are relatively specialized and cannot describe multiple problems and chemicals simultaneously.

Scaling issues, underlying processes simulated at various spatial scales, widely used models, and what the future holds for the NPS pollution models are discussed in this article. The need for a scale-independent model that can operate at multiple spatial and temporal scales and that can address the complex issues of the next century by coupling state-of-the-art understanding of multiple hydrogeological, geochemical, and microbiological processes was emphasized. A case was made that a scale-independent model was possible in the future. This conclusion was based on the availability of new technologies that will provide improved chemical analysis capabilities, affordable sensors, and hardware and software systems for transmission and analysis of data. Because of these technologies, better understanding of fundamental hydrogeological, geochemical, and microbiological processes will be developed, and spatial and temporal scaling issues will be resolved. Increased computing power will result in increased use of models through sophisticated graphical user interfaces. These improvements will lead to greater trust and acceptance of models in society and resolution of current and future complex environmental issues.

\section{ACKNOWLEDGEMENTS}

The authors wish to thank Wes Wallender, ASABE Soil and Water Division Editor, for his invitation to write this centennial article.

\section{REFERENCES}

Ahuja, L. R., and C. Hebson. 1992. Root Zone Water Quality Model. GPSR Tech. Report No. 2. Fort Collins, Colo.: USDA-ARS.

Arnold, J. G., and N. Fohrer. 2005. SWAT2000: Current capabilities and research opportunities in applied watershed modeling. Hydrol. Process. 19(3): 563-572.

Benham, B. L., K. M. Brannan, G. Yagow, R. W. Zeckoski, T. A. Dillaha, S. Mostaghimi, and J. W. Wynn. 2005. Development of bacteria and benthic total maximum daily loads: A case study, Linville Creek, Virginia. J. Environ. Qual. 34(5): 1860-1872.

Benham, B. L., C. Baffaut, R. W. Zeckoski, K. R. Mankin, Y. A. Pachepsky, A. M. Sadeghi, K. M. Brannan, M. L. Soupir, and M. J. Habersack. 2006. Modeling bacteria fate and transport in watersheds to support TMDLs. Trans. ASABE 49(4): 987-1002.

Bicknell, B. R., J. C. Imhoff, J. L. Kittle, Jr., T. H. Jobes, and A. S. Donigian, Jr. 2001. Hydrological Simulation Program FORTRAN, Version 12: User's Manual. Mountain View, Cal.: Aqua Terra Consultants.
Bierkens, F. P., P. A. Finke, and P. de Willigen. 2000. Upscaling and Downscaling Methods for Environmental Research. Dordrecht, The Netherlands: Kluwer Academic.

Bingner, R. L., and F. D. Theurer. 2003. AnnAGNPS Technical Processes Documentation, Version 3.2. Washington, D.C.: USDA-NRCS. A more recent version (2007) of this document is available at: www.wsi.nrcs.usda.gov/products/w2q/h\&h/tools_models/agnps/ downloads.html.

Bouraoui, F., and T. Dillaha. 1996. ANSWERS-2000: Runoff and sediment transport model. J. Environ. Eng. 122(6): 493-502.

Bouraoui, F., and T. Dillaha. 2000. ANSWERS-2000: Nonpoint-source nutrient planning model. J. Environ. Eng. 126(11): 1045-1055.

Borah, D. K., and M. Bera. 2003. Watershed-scale hydrologic and nonpoint-source pollution models: Review of mathematical bases. Trans. ASAE 46(6): 1553-1566.

Borah, D. K., and M. Bera. 2004. Watershed-scale hydrologic and nonpoint-source pollution models: Review of applications. Trans. ASAE 47(3): 789-803.

Borah, D. K., G. Yagow, A. Saleh, P. L. Barnes, W. Rosenthal, E. C. Krug, and L. M. Hauck. 2006. Sediment and nutrient modeling for TMDL development and implementation. Trans. ASABE 49(4): 967-986.

Bottcher, A. B., B. M. Jacobson, and J. G. Hiscock. 2005. TMDL assessment using WAM/WASP: Hillsborough River case study. In Proc. 3rd Conference Watershed Management to Meet Water Quality Standards and Emerging TMDL. St. Joseph, Mich.: ASAE.

Bradford, S. A., S. R. Yates, M. Bettehar, and J. Šimůnek. 2002. Physical factors affecting the transport and fate of colloids in saturated porous media. Water Resour. Res. 38(12): 63.1-63.12.

Brevé, M. A., R. W. Skaggs, J. E. Parsons, and J. W. William. 1997. DRAINMOD-N, A nitrogen model for artificially drained soils. Trans. ASAE 40(4): 1067-1075.

Carrillo-González, R., J. Šimůnek, S. Sauve, and D. Adriano. 2006. Mechanisms and pathways of trace element mobility in soils. Advances in Agronomy 91: 111-178.

Casey, F. X. M., and J. Šmůnek. 2002. Inverse analyses of the transport of chlorinated hydrocarbons subject to sequential transformation reactions. J. Environ. Qual. 30(4): 1354-1360.

Casey, F. X. M., G. L. Larsen, H. Hakk, and J. Šimůnek. 2003. Fate and transport of $17 \beta$-estradiol in soil-water systems. Environ. Sci. Tech. 37(11): 2400-2409.

Chung, S. O., A. D. Ward, and C. W. Schalk. 1992. Evaluation of the hydrologic component of the ADAPT water table management model. Trans. ASAE 35(2): 571-579.

Corwin, D. L., and R. J. Wagenet. 1996. Application of GIS to the modeling of nonpoint-source pollutants in the vadose zone: A conference overview. J. Environ. Qual. 25(3): 403-411.

Corwin, D. L., P. J. Vaughan, and K. Loague. 1997. Modeling nonpoint-source pollutants in the vadose zone with GIS. Environ. Sci. Tech. 31(8): 2157-2175.

Corwin, D. L., J. Hopmans, and G. D. de Rooij. 2006. From fieldto landscape-scale vadose zone processes: Scale issues, modeling, and monitoring. Vadose Zone J. 5(1): 129-139.

Debele, B., R. Srinivansan, and J.-Y. Parlange. 2006. Coupling upland watershed and downstream waterbody hydrodynamic and water quality models (SWAT and CE-QUAL-W2) for better water resources management in complex river basins. Environ. Model. Assess. DOI 10.1007/s10666-006-9075-1.

Donigian, A. S., Jr., and N. H. Crawford. 1976a. Modeling pesticides and nutrients on agricultural lands. EPA 600/2-7-76-043. Athens, Ga.: U.S. EPA Environmental Research Laboratory.

Donigian, A. S., Jr., and N. H. Crawford. 1976b. Modeling nonpoint pollution from the land surface. EPA 600/3-76-083. Athens, Ga.: U.S. EPA Environmental Research Laboratory. 
Dontsova, K. M., S. L. Yost, J. Šimůnek, J. C. Pennington, and C. Williford. 2006. Dissolution and transport of TNT, RDX, and composition B in saturated soil columns. J. Environ. Qual. 35(6): 2043-2054.

EMSI. 2007. Watershed Modeling System (WMS). South Jordan, Utah: Environmental Modeling Systems, Inc. Available at: www.ems-i.com/. Accessed February 2007.

Fayer, M. J. 2000. UNSAT-H Version 3.0: Unsaturated soil water and heat flow model: Theory, user manual, and examples. Report No. PNNL-13249. Richland, Wash.: U.S. Department of Energy, Pacific Northwest National Laboratory.

Flerchinger, G. N., C. L. Hanson, and J. R. Wight. 1996. Modeling evapotranspiration and surface energy budgets across a watershed. Water Resour. Res. 32(8): 2539-2548.

Foster, G. R., and L. D. Meyer. 1972. Transport of soil particles by shallow flow. Trans. ASAE 15(1): 99-102.

Haith, D. A., and L. L. Shoemaker. 1987. Generalized watershed loading functions for stream flow nutrients. Water Resour. Bulletin 23(3):471-478.

Hansen, S., H. E. Jensen, N. E. Nielsen, and H. Svendsen. 1990. DAISY: Soil plant atmosphere system model. NPO Report No. A 10. Copenhagen, Denmark: The National Agency for Environmental Protection.

Healy, R. W. 1990. Simulation of solute transport in variably saturated porous media with supplemental information on modifications to the U.S. Geological Survey's computer program VS2D. USGS Water-Resources Investigation Report 90-4025. Washington, D.C.: U.S. Geological Survey.

Hoosbeek, M. R., and R. B. Bryant. 1992. Towards the quantitative modeling of pedogenesis: A review. Geoderma 55(3-4): $183-210$.

Hutson, J. L., and R. J. Wagenet. 1992. LEACHM: Leaching estimation and chemistry model. Research Series No. 92-3. Ithaca, N.Y.: Cornell University.

Jacques, D., and J. Šimůnek. 2005 User manual of the multi-component variably saturated flow and transport model HP1: Description, verification, and examples. Version 1.0. SCK-CEN-BLG-998, Waste and Disposal. Mol, Belgium: SCK-CEN.

Jacques, D., J. Šimůnek, D. Mallants, and M. Th. van Genuchten. 2006. Operator-splitting errors in coupled reactive transport codes for transient variably saturated flow and contaminant transport in layered soil profiles. J. Contam. Hydrology 88(3-4): 197-218.

Jansson, P.-E., and L. Karlberg. 2001. Coupled Heat and Mass Transfer Model for Soil-Plant-Atmosphere Systems. Stockholm, Sweden: Royal Institute of Technology, Department of Civil and Environmental Engineering.

Jarvis, N. J. 1994. The MACRO model (Version 3.1): Technical description and sample simulations. Reports and dissertations 19. Uppsala, Sweden: Swedish University of Agricultural Science, Department of Soil Science.

Kandil, H. M., R. W. Skaggs, S. Abdel Dayem, and Y. Aiad. 1995. DRAINMOD-S: Water management model for irrigated arid lands, crop yield, and applications. Irrig. Drain. Systems 9(3): 239-258.

Knisel, W. G. 1980. CREAMS: A field-scale model for chemicals, runoff, and erosion from agricultural management systems. USDA Conservation Research Report No. 26. Washington, D.C.: USDA-ARS.

Knisel, W. G., ed. 1993. GLEAMS: Ground Water Loading Effects of Agricultural Management Systems. Ver. 2.10. VGA-CPESBAED Publ. No. 5. Tifton, Ga.: University of Georgia, Coastal Plain Experiment Station.

Knisel, W. G., and F. M. Davis. 1999. GLEAMS: Groundwater Loading Effects of Agricultural Management Systems. Version 3.0 Users Manual. SEWRL-WGK/FMD-050199. Tifton, Ga.: USDA-ARS Southeast Watershed Research Laboratory.
Laflen, J. M., L. J. Lane, and G. R. Foster. 1991. WEPP: A new generation of erosion prediction technology. J. Soil Water Cons. 46(1): 34-38.

Leonard, R. A., W. G. Knisel, and D. A. Still. 1987. GLEAMS: Groundwater Loading Effects of Agricultural Management Systems. Trans. ASAE 30(5): 1403-1428.

Meyer, L. D., and W. H. Wischmeier. 1969. Mathematical simulation of the process of soil erosion by water. Trans. ASAE 12(6): 754-762.

Migliaccio, K. W., and P. Srivastava. 2007. Modeling hydrology at the watershed scale. Trans. ASABE 50(5): 1695-1703.

Muñoz-Carpena, R., R. G. Vellidis, A. Shirmohammadi, and W. W. Wallender. 2006. Evaluation of modeling tools for TMDL development and implementation. Trans. ASABE 49(4): 961-966.

Neitsch, S. L., J. G. Arnold, J. R. Kiniry, J. R. Williams, and K. W. King. 2002. Soil and Water Assessment Tool: Theoretical documentation, Version 2000. Temple, Tex.: Blackland Research Center and USDA-ARS Grassland Soil and Water Research Laboratory. Available at: www.brc.tamus.edu/ swat/downloads/doc/swat2000theory.pdf. Accessed May 2005.

Niu, Z., G. Sun, S. G. McNulty, M. Xie, and W. Byne. 2001. Applying ANSWERS-2000 to simulate BMP effects on sediment and runoff from two watersheds in the Three Gorges Area, southern China. In Soil Erosion Research for the 21st Century, Proc. Intl. Symp., 653-656. ASAE Pub. No. 701P0007. J. C. Ascough II and D. C. Flanagan, eds. St. Joseph, Mich.: ASAE.

Ouyang, Y. 2003. Simulating dynamic load of naturally occurring TOC from watershed into a river. Water Res. 37(4): 823-832.

Parkhurst, D. L., and C. A. J. Appelo. 1999. User's guide to PHREEQC: A computer program for speciation, batch-reaction, one-dimensional transport, and inverse geochemical calculations. Version 2. USGS Water-Resources Investigation Report 99-4259. Denver, Colo.: U.S. Geological Survey.

Parkhurst, D. L., K. L. Kipp, P. Engesgaard, and S. C. Charlton. 2004. PHAST: A program for simulating groundwater flow, solute transport, and multi-component geochemical reactions. USGS Techniques and Methods 6-A8.

Paul, S., P. K. Hann, M. D. Matlock, S. Mukhtar, S. D. Pillai. 2004. Analysis of the HSPF water quality parameter uncertainty in predicting peak in-stream fecal coliform concentrations. Trans. ASAE 47(1): 69-78.

Pruess, K. 1991. TOUGH2: A general-purpose numerical simulator for multiphase fluid and heat flow. Report LBL-29400. Berkeley, Cal.: Lawrence Berkeley Laboratory.

Renard, K. G., G. R. Foster, G. A. Weesies, and J. P. Porter. 1991. RUSLE: Revised Universal Soil Loss Equation. J. Soil Water Cons. 46(1): 30-33.

Richards, L. A. 1931. Capillary conduction of fluid through porous mediums. Physics 1: 318-333.

Ritchie, J. T. 1972. A model for simulating evaporation from a row crop with incomplete cover. Water Resour. Res. 8(5): 1204-1213.

Saito, H., J., J. Šimůnek, and B. Mohanty. 2006. Numerical analyses of coupled water, vapor, and heat transport in the vadose zone. Vadose Zone J. 5(2): 784-800.

Saleh, A., and B. Du. 2004. Evaluation of SWAT and HSPF within BASINS program for the Upper North Bosque River watershed in central Texas. Trans. ASAE 47(4): 1039-1049.

Saleh, A., J. G. Arnold, P. W. Gassman, L. M. Hauck, W. D. Rosenthal, J. R. Williams, and A. M. S. McFarland. 2000. Application of SWAT for the Upper North Bosque River watershed. Trans. ASAE 43(5): 1077-1087.

Schaerlaekens, J., D. Mallants, J. Simůnek, M. Th. van Genuchten, and J. Feyen. 1999. Numerical simulation of transport and sequential biodegradation of chlorinated aliphatic hydrocarbons using CHAIN_2D. Hydrol. Process. 13(17): 2847-2859. 
Schijven, J., and J. Šimůnek. 2002. Kinetic modeling of virus transport at field scale. J. Contam. Hydrol. 55(1-2): 113-135.

Seuntjens, P., K. Tirez, J. Šimůnek, M. Th. van Genuchten, C. Cornelis, and P. Geuzens. 2001. Aging effects on cadmium transport in undisturbed contaminated sandy soil columns. $J$. Environ. Qual. 30(3): 1040-1050.

Shaffer, M. J., A. D. Halverson, and F. J. Pierce. 1991. Nitrate leaching and economic analysis package (NLEAP): Model description and application. In Managing Nitrogen for Groundwater Quality and Farm Profitability, 285-322. R. F. Follett, D. R. Kenney, and R. M. Cruse, eds. Madison, Wisc.: SSSA.

Šimůnek, J. 2005. Chapter 78: Models of water flow and solute transport in the unsaturated zone. In Encyclopedia of Hydrological Sciences, 1171-1180. M. G. Anderson and J. J. McDonnell, eds. Chichester, U.K.: John Wiley and Sons.

Šimůnek, J., and A. J. Valocchi. 2002. Chapter 6.9: Geochemical transport, Part 1: Physical methods. In Methods of Soil Analysis, 1511-1536. 3rd ed. J. H. Dane and G. C. Topp, eds. Madison, Wisc.: SSSA.

Šimůnek, J., M. Th. van Genuchten, M. Šejna, N. Toride, and F. J. Leij. 1999. The STANMOD computer software for evaluating solute transport in porous media using analytical solutions of convection-dispersion equation. Versions 1.0 and 2.0. IGWMC-TPS-71. Golden, Colo.: Colorado School of Mines, International Ground Water Modeling Center.

Šimůnek, J., M. Th. van Genuchten, and M. Šejna. 2005. The HYDRUS-1D software package for simulating the one-dimensional movement of water, heat, and multiple solutes in variably saturated media. Version 3.0. HYDRUS Software Series 1. Riverside, Cal.: University of California, Department of Environmental Sciences.

Šimůnek, J., M. Th. van Genuchten, and M. Šejna. 2006. The HYDRUS software package for simulating two- and three-dimensional movement of water, heat, and multiple solutes in variably saturated media: Technical manual. Version 1.0. Prague, Czech Republic: PC Progress.

Singh, V. P., and D. A. Woolhiser. 2002. Mathematical modeling of watershed hydrology. J. Hydrol. Eng. 7(4): 270-292.

Sivapalan, M., R. Grayson, and R. Woods. 2004. Scale and scaling in hydrology. Hydrol. Process. 18(8): 1369-1371.

Skaggs, W. F. 2007. DRAINMOD. Raleigh, N.C.: North Carolina State University, Department of Biological and Agricultural Engineering. Available at:

www.bae.ncsu.edu/soil_water/drainmod.htm. Accessed February 2007.

Steefel, C. I. 2000. New directions in hydrogeochemical transport modeling: Incorporating multiple kinetic and equilibrium reaction pathways. In Computational Methods in Water Resources XIII, 331-338. L. R. Bentley, J. F. Sykes, C. A. Brebbia, W. G. Gray, and G. F. Pinder, eds. Rotterdam, The Netherlands: A. A. Balkema.

Suttles, J. B., G. Vellidis, D. D. Bosch, R. Lowrance, J. M. Sheridan, and E. L. Usery. 2003. Plain streams using the annualized AGNPS model. Trans. ASAE 46(5): 1325-1335.

SWET. 2006. Watershed Assessment Model documentation and user's manual. Gainesville, Fla.: Soil and Water Engineering Technology, Inc. Available at: www.swet.com/SoftwareWAMUsersManual.html. Accessed February 2007.

Theurer, F. D., and C. D. Clarke. 1991. Wash load component for sediment yield modeling. In Proc. 5th Federal Interagency Sedimentation Conf., 7-1 to 7-8. Washington, D.C.: Federal Energy Regulatory Commission.

Tremwel, T. K. 1992. Field hydrologic and nutrient transport model, FHANTM. PhD diss. Gainesville, Fla.: University of Florida.

USEPA. 2007. Better Assessment Science Integrating Point and Nonpoint Sources (BASINS). Washington, D.C.: U.S. EPA.
Available at: www.epa.gov/waterscience/basins/. Accessed February 2007.

van Dam, J. C., J. Huygen, J. G. Wesseling, R. A. Feddes, P. Kabát, P. E. V. van Valsum, P. Groenendijk, and C. A. van Diepen. 1997. Theory of SWAP, version 2.0: Simulation of water flow, solute transport, and plant growth in the soil - water atmosphere - plant environment. Wageningen, The Netherlands: Wageningen Agricultural University, Department of Water Resources (Report 71), and DLO Winand Staring Centre (Technical Document 45).

Vanderborght, J., R. Kasteel, and H. Vereecken. 2006. Stochastic continuum transport equations for field-scale solute transport: Overview of theoretical and experimental results. Vadose Zone J. 5(1): 184-203.

van Genuchten, M. Th. 1987. A numerical model for water and solute movement in and below the root zone. Research Report No 121. Riverside, Cal.: USDA-ARS U.S. Salinity laboratory.

Van Liew, M. W., J. G. Arnold, and J. D. Garbrecht. 2003. Hydrologic simulation on agricultural watersheds: Choosing between two models. Trans. ASAE 46(6): 1539-1551.

Vellidis, G., P. Barnes, D. D. Bosch, and A. M. Cathey. 2006. Mathematical simulation tools for developing dissolved oxygen TMDLs. Trans. ASABE 49(4): 1003-1022.

Verburg, K., P. J. Ross, and K. L. Bristow. 1996. SWIM v. 2.1 User Manual. Divisional Report 130. Clayton South, Victoria, Australia: CSIRO.

Wagenet, R. J., and J. L. Hutson. 1996. Scale-dependency of solute transport modeling/GIS applications. J. Environ. Qual. 25(3): 499-510.

White, K. L., and I. Chaubey. 2005. Sensitivity analysis, calibration, and validation for a multisite and multivariable SWAT model. $J$. American Water Resources Assoc. 41(5): 1077-1078.

White, K. L., I. Chaubey, and B. Haggard. 2004. Linking watershed and reservoir models. In Proc. 2004 ASAE/CSAE Annual International Meeting. St. Joseph, Mich.: ASAE.

Williams, J. R., and R. C. Izaurralde. 2005. The APEX model. BRC Report 2005-02. Temple, Tex.: Blackland Research Center.

Williams, J. R., C. A. Jones, and P. T. Dyke. 1984. A modeling approach to determining the relationship between erosion and soil productivity. Trans. ASAE. 27(1): 129-144.

Woods, S. A., R. G. Kachanoski, and M. F. Dyck. 2006. Long-term solute transport under semi-arid conditions: Pedon and field scale. Vadose Zone J. 5(1): 365-376.

Woolhiser, D. A., R. E. Smith, and D. C. Goodrich. 1990. KINEROS, A kinematic runoff and erosion model: Documentation and user manual. ARS-77. Washington, D.C.: USDA-ARS.

Yagow, G., B. Wilson, P. Srivastava, and C. C. Obropta. 2006. Use of biological indicators in TMDL assessment and implementation. Trans. ASABE 49(4): 1023-1032.

Yeh, G.-T., and H.-P. Cheng. 1999. 3DHYDROGEOCHEM: A 3-dimensional model of density-dependent subsurface flow and thermal multispecies-multicomponent hydrogeochemical transport. EPA/600/R-98/159. Washington, D.C.: U.S. EPA.

Young, R. A., C. A. Onstad, D. D. Bosch, and W. P. Anderson. 1987. AGNPS, Agricultural Nonpoint-Source Pollution model: A large watershed analysis tool. Conservation Research Report No. 35. Washington, D.C.: USDA.

Yuan, Y., R. L. Bingner, and R. A. Rebich. 2001. Evaluation of AnnAGNPS on Mississippi Delta MSEA watersheds. Trans. ASAE 44(5): 1183-1190.

\section{NOMENCLATURE} 3DHYDROGEOCHEM

3-dimensional model of flow and thermal multispeciesmulticomponent hydro geochemical transport 


\begin{tabular}{|c|c|c|c|}
\hline ADAPT & $\begin{array}{l}\text { Agricultural Drainage and } \\
\text { Pesticide Transport }\end{array}$ & HYDRUS & $\begin{array}{l}\text { Variably saturated water flow } \\
\text { and solute transport model }\end{array}$ \\
\hline AGNPS & Agricultural Nonpoint Source & HSPF & Hydrologic Simulation \\
\hline \multirow[t]{2}{*}{ AnnAGNPS } & Annualized Agricultural Non & & Program - Fortran \\
\hline & point Source & HUSLE & Hydrogeomorphic USLE \\
\hline \multirow[t]{2}{*}{ ANSWERS } & $\begin{array}{l}\text { Areal Nonpoint Source } \\
\text { Watershed Environment }\end{array}$ & LEACHM & $\begin{array}{l}\text { Leaching Estimation and } \\
\text { Chemistry Model }\end{array}$ \\
\hline & Response Simulation & MACRO & Variably saturated water flow \\
\hline \multirow[t]{2}{*}{ APEX } & Agricultural Policy/ & & model for macroporous soils \\
\hline & Environmental Extender & MUSLE & Modified USLE \\
\hline BASINS & $\begin{array}{l}\text { Better Assessment Science } \\
\text { Integrating Point and } \\
\text { Nonpoint Sources }\end{array}$ & PHAST & $\begin{array}{l}\text { Computer program for } \\
\text { simulating groundwater flow, } \\
\text { solute transport, and multi }\end{array}$ \\
\hline \multirow[t]{2}{*}{ COUP } & $\begin{array}{l}\text { Coupled heat and mass } \\
\text { transfer model for soil-plant- }\end{array}$ & & $\begin{array}{l}\text { component geochemical } \\
\text { reactions }\end{array}$ \\
\hline & atmosphere system & PHREEQC & Geochemical model \\
\hline \multirow[t]{2}{*}{ CREAMS } & Chemicals, Runoff, Erosion & RUSLE & Revised USLE \\
\hline & $\begin{array}{l}\text { from Agricultural } \\
\text { Management Systems }\end{array}$ & RZWQM & $\begin{array}{l}\text { Root-Zone Water Quality } \\
\text { Model }\end{array}$ \\
\hline \multirow[t]{3}{*}{ CRUNCH } & Computer program for multi & SHAW & Simultaneous Heat and Water \\
\hline & component reactive transport & SWAP & Soil Water Atmosphere Plant \\
\hline & in porous media & SWAT & Soil and Water Assessment \\
\hline DAISY & Crop/soil simulation model & & Tool \\
\hline DRAINMOD & Drainage Model & SWIM & Variably saturated water flow \\
\hline DRAINMOD-N & Drainage Model for Nitrogen & & model \\
\hline DRAINMOD-S & Drainage Model for Salinity & TOUGH2 & Transport of Unsaturated \\
\hline \multirow[t]{2}{*}{ EAAMOD } & Everglades Agricultural Area & & Groundwater and Heat \\
\hline & Model & UNSATCHEM & Unsaturated water flow model \\
\hline \multirow{2}{*}{ EPIC } & Erosion Productivity Impact & & with major ion chemistry \\
\hline & Calculator & UNSATH & Unsaturated water flow model \\
\hline \multirow[t]{2}{*}{ FHANTM } & Field Hydrologic and Nutrient & USLE & Universal Soil Loss Equation \\
\hline & Transport Model & VS2DT & Variably Saturated 2-D Flow \\
\hline \multirow[t]{3}{*}{ GLEAMS } & Groundwater Loading Effects & & and Transport model \\
\hline & of Agricultural Management & WAM & Watershed Assessment Model \\
\hline & Systems & WMS & Watershed Modeling System \\
\hline
\end{tabular}


